\title{
Offshoring and export performance in the european automotive industry
}

Raphaël Chiappini

\section{LAREFI Working Paper CR11-EFI/04}

2011

http://lare-efi.u-bordeaux4.fr

\author{
LAREFI
}

Université Montesquieu-Bordeaux IV

Bâtiment Recherche Economie

Avenue Léon Duguit - 33608 Pessac 
Abstract This paper investigates the impact of offshoring on export performances of French, German and Italian automotive firms. We argue that the different offshoring strategies run by the main European automakers are responsible for the discrepancies in export performances of France, Germany and Italy on the world automotive market. We use an export equation and a panel data analysis and show that offshoring strongly affect exports of automotive firms. Focussing on the French and German export performances, we show that the relatively low export performance of France in the automotive industry since the end of the 1990s is mainly the result of an increase in offshoring lead by Renault and PSA.

Keywords Offshoring, export performance, automotive industry

JEL Classification F14, C23, C26 


\section{Introduction}

Over the past decades, the automotive industry have experienced drastic changes in its production processes. Indeed, globalization has allowed the international product fragmentation, i.e. the splitting-up of the production process into separate components so that goods can be produced in different locations. The production is divided into different stages, which can be located in different plants inside or outside the home country. As a consequence, international product fragmentation is associated with a huge increase of trade in intermediates goods. According to Dicken (2007), the automotive industry is considered as one of the most globalized industry. Thus, automotive firms organize their activity in a global value chain (Sturgeon and al.) and separate different production stages across the world economy to exploit lower production costs in emerging countries. Therefore, automakers in Europe and USA have outsourced an increasing share of automotive production to emerging countries and buy parts and components from foreign suppliers rather than producing them in their own firm. For example, Miguel-Fernandez and al. (2001) and Blacet and Enrietti (2002) showed that Fiat has increased the international outsourcing of its production in MERCOSUR member countries and Poland. In 2008, the four main European automakers have foreign affiliates in several emerging countries: Volkswagen in South America (Argentina, Brazil and Mexico), Eastern and European Countries (Czech Republic, Hungary, Poland, Russia and Slovakia), South Africa and China, Renault in Africa (Morocco, South Africa), South America (Argentina, Brazil, Colombia and Mexico), Asia (India, Indonesia and Iran), Eastern and European Countries (Romania, Russia and Slovenia) and Turkey, PSA in Africa (Morocco and Nigeria), South America (Argentina and Brazil), Asia (China and Iran), Eastern and European Countries (H and Slovakia) and Turkey and Fiat in South America (Argentina and Brazil), Asia (China and India), Eastern and European Countries (Hungary and Poland) and Turkey ${ }^{1}$.

Nevertheless, the international fragmentation of production can be run in different ways (Ruigrok and Van Tulder, 1995). On the one hand, automakers can outsource different stages of the production in foreign countries and buy intermediate products such as parts from foreign suppliers in order to re-export the final product from the home country. This strategy implies international outsourcing, vertical intra-industry trade (Türkcan and Ates, 2010) and vertical specialization (Hummels and al., 2001). The international outsourcing of automotive

\footnotetext{
${ }^{1}$ See appendix 1.
} 
production is, for example, used by German automakers such as Audi or Volkswagen. On the other hand, another strategy for an automaker consists in outsourcing the total production of the final product in a foreign market. Therefore, the final product is no longer exported by the home country but from the foreign country. This strategy does not imply vertical specialization and referred to "offshoring" in the empirical literature (Olsen, 2006; Jabbour, 2010; Mc Cann, 2011). This strategy is, for instance, used by Renault in Slovenia, where the Clio II and the Twingo II are produced in their entirety in the Revoz factory and directly exported by Slovenia to its main trade partners. Note that these strategies can be run by a same automaker for different models of cars, especially the down-market vehicles and the high-end vehicles, and that they decrease the home production while they increase the foreign production.

Therefore, the automotive production of motor vehicles carried out by emerging countries has experienced an unprecedented growth during the last decade, especially in China (Péridy and Abdeni, 2008). This growth concerns all the emerging markets. According to the International Organization of Motor Vehicle Manufacturer (OICA), between 1999 and 2008, the production of motor vehicles increased by $28 \%$ in Central and Eastern Europe, 134 $\%$ in South America and $93 \%$ in Africa. Moreover, the production of motor vehicles has been multiplied by 4 in China, 3.5 in Slovakia, 1.8 in India, 1.5 in Czech Republic and Brazil, and 1.3 in Romania ${ }^{2}$. As a consequence, China is the second largest producer of motor vehicles in 2008, before the USA and Germany but behind Japan. In 1999, China was just the ninth producer far behind the USA, Japan and Germany.

During the same period, the French share in the world automotive market decreased from $7.5 \%$ to $5.8 \%$, whereas the German share slightly increased from $18.3 \%$ in 1997 to $18.6 \%$ in 2008 . The Italian export market share diminished (3.2\% in 2008 compared with $4 \%$ in 1997). For these three countries, the share of the automotive sector into the total exports is very large since in 2008 it represented $16 \%$ of German exports, 11\% of French exports and $8 \%$ of Italian exports. In 2008, Germany was the largest global exporter in the automotive sector, France was the fourth largest and Italy was the tenth.

How can we explain this phenomenon given that these three countries share the same currency since 1999? Why have German automotive firms increased their export market share in the world market, whereas French and Italian firms reduced it? Are the different offshoring strategies lead by French, German and Italian automakers responsible for those discrepancies?

\footnotetext{
${ }^{2}$ For more details, see appendix 2.
} 
In this paper, we run an export equation using panel data for France, Germany and Italy and an indicator for offshoring. We show that the increase in offshoring has a negative and a significant impact on the evolution of the exports in the selected countries. Focussing on the differences between France and Germany, we show that the relatively low performance of French automotive firms on the world market is mainly due to increasing labour costs and an increasing offshoring strategy run by French automakers since the end of the 1990s. On the contrary, German firms still produce more inland than abroad but have increased the international fragmentation of production and their vertical specialization, which illustrates the theory of "Bazaar Effect" (Sinn, 2004, 2006).

This paper is structured as follows. In the following section, we discuss the theoretical link between outsourcing, offshoring, vertical specialization and exports, and their measures. In section 3, we describe the data and specify the empirical model. Section 4 presents the main results of our panel data analysis and section 5 concentrates on the French and German case. Section 6 concludes.

\section{Offshoring, outsourcing, vertical specialization and exports} a- Concepts

Generally, there exists a confusion between offshoring and outsourcing in the literature. However, these two concepts are very different and depend on the firm decision of sourcing along two dimensions: the firm boundary and location. Olsen (2006) presents the decision matrix described in Figure 1.

Figure 1 Firm's sourcing modes (Olsen, 2006)

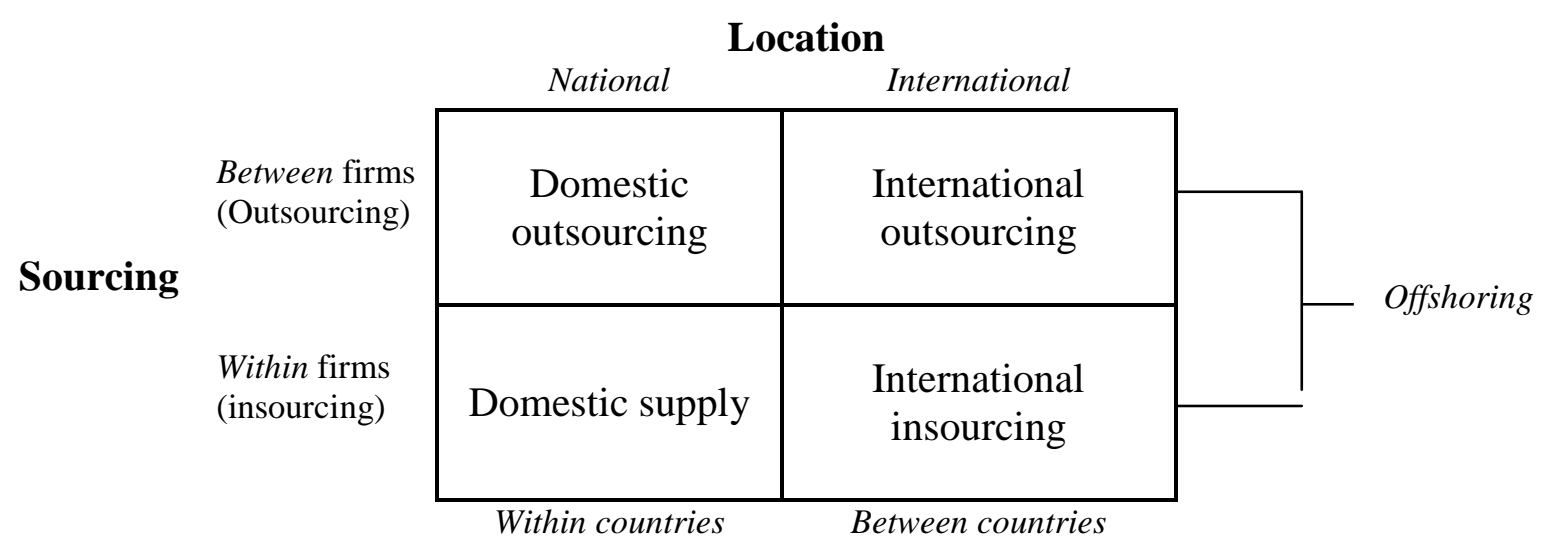


Firms have therefore several choices for their sourcing strategy. They can source their inputs purely domestically, either by producing all inputs in their own plant (bottom-left hand corner) or by combining this with sourcing from local plants (top left hand corner). The firm can also produce its inputs outside its country, either by a foreign supplier (international outsourcing) or by its own company on a foreign country (international insourcing). Therefore, outsourcing refers to the purchase of goods and services that were previously produced inside the purchasing company. The firm providing the intermediate inputs can be located inside (domestic outsourcing) or outside (international outsourcing) the country of the sourcing company. Then, offshoring "refers to the purchase from companies in locations outside the country of goods and services previously produced inside the company. Thus, it includes not only international outsourcing, but also international insourcing" (Molnar and al., 2007, p. 8). Offshoring is therefore a wider strategy and can take place within the boundaries of the firm (vertical FDI) or through market transactions (international outsourcing). We, then, assume that offshoring includes the total production of a good in a foreign country, whereas international outsourcing implies the fragmentation of the production process and imports of intermediates inputs from abroad.

The concept of vertical specialization has been introduced by Hummels et al. (2001). It occurs when a good is produced in two or more sequential stages, when two or more countries provide value-added during the production of the good and when at least one country must use imported inputs in the production process, and some of the resulting output must be exported. Vertical specialization thus implies exports of the final product.

Here we take the example of the production of Audi cars in Germany ${ }^{3}$. We know that Audi produces its cars at Ingolstadt in Germany. Nevertheless, since 1993, the engine production of Audi cars has been outsourced to Györ in Hungary. Therefore, Germany imports engines from Hungary and finishes the production of the Audi cars in Ingolstadt. If, the car is only sold on the German market, there is no vertical specialization. Otherwise, -i.e. if the car is exported to a trading partner vertical specialization occurs. So, vertical specialization implies international outsourcing but the reverse is not true.

If we now take the example of the production of the Clio II in Slovenia ${ }^{4}$. Since 1998, the Clio II is produced in its entirety in Slovenia. In this case, France imports the car directly from Slovenia, for its own market. So, there is no vertical specialization because the Clio II is

\footnotetext{
${ }^{3}$ See appendix 3

${ }^{4}$ See appendix 4
} 
no longer exported by France but from Slovenia. In this offshoring process, no vertical specialization has occurred.

A lot of empirical studies have provided descriptive statistics on the importance of vertical specialization using different measures (Feenstra, 1998; Hummels et al., 2001; Yeats, 2001; Kimura and Ando, 2005; Ando, 2006). These studies show the increasing share of vertical intra-industry in the total world trade. The link between trade and vertical specialization has been studied by Sinn $(2004,2006)$ where he introduces the "Bazaar theory". In his work, he finds that Germany has begun to split the value-added chain in different stages over different countries from the end of the 1990s. This strategy aims at reducing the production costs of German firms. It entails an increase in imports of intermediate products and a huge increase in exports. However, the value-added created by Germany has begun to decrease, because the value added by German firms is relatively low. According to this study, Germany has benefited from its international outsourcing strategy. However, this analysis is not based on an empirical approach and the link between German exports and vertical specialization has not been tested yet. Bouhlol (2006) has tried to explain the discrepancies in export performances of France and Germany using an indicator of vertical specialization. He shows that Germany has benefited from its vertical specialization, but his model only includes two indicators of vertical specialization since important explanatory variables such as prices or demand are omitted. More recent research from ErkelRousse and Garneiro (2008) and Danninger and Joutz (2008) shows a positive link between the German vertical specialization and the evolution of its export market share using export equations. However, the impact of total offshoring of production on exports performances via a "misappropriation effect" has not been tested.

\section{$b$ - Measures}

The extent of international fragmentation is difficult to measure accurately. The empirical literature on trade suggests a range of different methods and data sources to quantify these activities. Three main data sources have been used to document the international fragmentation of production at the sectoral level: (i) customs statistics on processing trade, (ii) international trade statistics on parts and components, and (iii) Input-Output (I-O) tables. Feenstra and Hanson (1996) and Feenstra and Hanson (1999) consider two different measures for international outsourcing: a broad and a narrow measure. The broad measure is defined as the value of all imported intermediates inputs of an industry, while the narrow measure 
restricts attention to intermediates inputs from the same industry as the good being produced. Hummels et al.(2001) have improved those measurements in defining vertical specialization (VS), which can be expressed in terms of gross output. Following this study, Breda et al. (2008), and Amador and Cabral (2009) tried to measure the vertical specialization of European countries in different sectors using the input-output tables and the import content of exports. Belke, Mattes and Wang (2007) applied the same methodology in order to explain the German strategy and its vertical specialization. Finally, we can measure the vertical specialization (VS) as follows (Hummels et al., 2001):

$$
V S_{i, k}=\left(\frac{\text { imported intermediates }}{\text { gross outpust }}\right) * \text { exports }
$$

$\mathrm{VS}_{\mathrm{i}, \mathrm{k}}$, represents the vertical specialization of country $i$ in sector $k$. This measure is based on the diagonal of input-output tables and represents the import content of exports. Following this approach, we calculate the vertical specialization (VS) for France, Germany and Italy in the automotive sectors. Results are summarized in table 1. 
Table 1: Import content of exports in the automotive sector (VS indicator)

\begin{tabular}{lcccc}
\hline & Mid-1990s & Early 2000s & Mid-2000s & Evolution \\
\hline \hline France & 0,278 & 0,346 & 0,359 & $29 \%$ \\
Germany & 0,231 & 0,273 & 0,300 & $30 \%$ \\
Italy & 0,267 & 0,307 & 0,307 & $15 \%$ \\
\hline Source: OECD database & & & &
\end{tabular}

Our results show an expansion in international outsourcing for the three countries under scrutiny in the automotive sector. We can also remark that the strongest increase in vertical specialization between the mid-1990s and the mid-2000s has been recorded in Germany and France. As a result, the import content of French and German automotive exports have experienced a strong growth during this period. Note that the vertical specialization of the French automotive industry is stronger than the Italian and the German one, but this discrepancy already existed in the mid-1990s.

Nevertheless, as discussed below this notion of vertical specialization is too narrow to take into account the total relocation of production included in the "offshoring" notion. We need a wider measure which captures both fragmentation of production and total relocation production.

Using data from the OICA, we compute a measure of foreign content of production (offshoring), which is defined as the ratio between the production of automotive products carried abroad for country $i$ and the total production of automotive products of country $i$ :

$$
O F F_{i, k}=\frac{\text { Foreign prodwotion }}{\text { Total prodisetion }}
$$

We compute this measure for French, German and Italian automakers since 1997. Our results are reported in table 2 and in appendix 5.

Table 2: Offshoring from French, German and Italian automakers

\begin{tabular}{lcccc}
\hline & Mid-1990s & Early 2000s & Mid-2000s & Evolution \\
\hline \hline French automakers* & 0,372 & 0,407 & 0,528 & $42 \%$ \\
German automakers** & 0,383 & 0,432 & 0,484 & $26 \%$ \\
Italian automakers*** & 0,420 & 0,400 & 0,524 & $25 \%$ \\
\hline Source: CCFA, VDA, OICA & \multicolumn{4}{l}{ Note: *erman automakers include Audi, BMW, Opel, Porsche and Volkswagen } \\
$\quad$ **: French automakers include PSA and Renault (including Renault Trucks) \\
$\quad$ ***: Italian automakers include Fiat-Iveco-Irisbus
\end{tabular}

Our findings show the huge increase in the foreign content of production for French automakers since the mid-1990s. In fact, over the recent period, the two largest French manufacturers, PSA and Renault, have strongly developed their international offshoring 
strategy. These two car makers produce far more cars abroad than they do in France, since 2005 for Renault and 2007 for PSA. They notably benefit from the fast growing demand and the advantageous production conditions in emerging countries, notably the new member states of the European Union. The down-market cars are also mainly manufactured abroad. Only the production of the high-end vehicles is still carried out in its entirety in France. Although the French manufacturers used to export their down-market vehicles from France, they now sell them directly from their new manufacturing sites abroad. Various export platforms are indeed situated in Eastern Europe ${ }^{5}$ to serve the production zone as well as the traditional clients of the French manufacturers in Western Europe.

For Italian car-makers, results are the same as for France, since 2004, they produce more abroad than they do in Italy. But on the contrary to French automakers, the trend is not recent and grows more slowly. Indeed, the takeover of FSO, a Polish car manufacturer, in 1993 created Fiat Auto Poland, a majority controlled affiliate. It offered opportunities for the systematic integration of the activity in Poland within Fiat's regional productive structure in Europe. Fiat produces the down-market model abroad and particularly in Brazil and Poland. On the contrary, German car makers still produce more than half of their cars inland. Germans car-makers follow a different strategy: they split up the value-added chain and use the New International Division of Labour. They import intermediates products in order to re-export the final product from Germany. This is what Sinn $(2004,2006)$ called the "Bazaar Effect". For example, the Porsche Cayenne is seemingly produced in Leipzig, but it turns out that the assembly line is located in Bratislava, Slovakia. Little more than the engine is added in Leipzig. According to a study by Dudenhöffer (2005), only about a third of the production value of that car is generated in Germany.

Therefore, the two measures- vertical specialization $\left(V S_{i, k}\right)$ and offshoting $\left(O F F_{i, k}\right)$ describe two different strategies for the main European automakers. If French and Italian automakers have accelerated the total relocation of production in emerging countries, German automotive seem to rely more on the international fragmentation of production.

\section{Empirical approach}

a- The model

\footnotetext{
${ }^{5}$ the Czech Republic and Slovakia for the PSA Group, in Slovenia and Romania by its sister company Dacia and in Russia for the Renault group.
} 
The empirical strategy is to test whether that offshoring had a significant impact on French, German and Italian automotive exports. We, then, rely on an export equation (Armington, 1969) for the automotive industry. This class of model tries to explain the export performance (X) of a country for a given sector according to the demand for specific products (WD) and the evolution of the export prices ( $(\mathrm{Pr})$. In fact, different geographic specialisation can be translated in weaker foreign demand. Also, countries that export to strong growth zones experience an increased demand, which results in a higher market share. The global demand has therefore a positive impact on growth of the export market shares. Besides, the price competitiveness holds a very important role in the growth of export market shares. It is reflected in the capacity of a country to offer lower prices than others on the global market. More recent studies (Erkel-Rousse and Garneiro, 2008) have focussed on the costcompetitiveness using a Unit Labour Costs (ULC) index. The traditional export equations omit non-price competitiveness factors like quality or innovation. Indeed, some manufacturers are specialised in luxury, high quality cars such as Ferrari (Italy) or Audi, BMW, Mercedes and Porsche (Germany). The non-price competitiveness is therefore important to assess a country's export performance (Garel Rhys, 2005). The empirical literature then uses a proxy for the non-price competitiveness based on the Research and Development expenditures (Fagerberg, Hummels and Klenow, Blot and Cochard)Then, as in Péridy and Abedini (2008) we have a proxy of $\mathrm{R} \& \mathrm{D}$ expenses in our export equation for the automotive industry. Domestic conditions are also important to assess in export equations (Blot and Cochard, 2008). We then add two variables: one captures the condition on the domestic market- the relative capacity utilisation ratio- and the other captures the productivity of the automotive sector in each country. When referring to the automotive industry, another factor can affect the sales in the different markets: the real oil price (Hugh et al., 2010). Therefore, our model takes into account the evolution of the oil price on the world market. We also include our offshoring indicator in the final equation. Finally, our export equation has the following form:

$$
\begin{aligned}
& \ln \left(X_{i, t}\right)=\beta_{1} \ln \left(W D_{i, t}\right)+\beta_{2} \ln \left(U L C_{i, t}\right)+\beta_{3} \ln \left(r R D_{i, t}\right)+\beta_{4} \ln (P R O D)+\beta_{5} \ln \left(r C U_{i, t}\right)+ \\
& \beta_{6} \ln \left(r O F F_{i, t}\right)+\beta_{7} \ln \left(O L L_{t}\right)+\varepsilon_{i, t}
\end{aligned}
$$

With $\mathrm{X}_{\mathrm{i}, \mathrm{t}}$, the passenger cars exports of country $i$ on date $t, \mathrm{WD}_{\mathrm{i}, \mathrm{t}}$, the global demand with reference to the automotive sector of country $i$ on date $t$ based on the new passenger cars registrations, $\mathrm{ULC}_{\mathrm{i}, \mathrm{t}}$, the Unit Labour Cost index in the automotive sector of country $i$ on date 
$t, \mathrm{rRD}_{\mathrm{i}, \mathrm{t}}$ the relative expenditure on $\mathrm{R} \& \mathrm{D}$ of country $i$ on date $t$ in the automotive sector based on the value added, $\operatorname{PROD}_{\mathrm{i}, \mathrm{t}}$, the productivity of country $i$ in the automotive sector on date $t, \mathrm{rDD}_{\mathrm{i}, \mathrm{t}}$ the relative capacity utilization ratio of country $i$ on date $t$ in the automotive sector, $\mathrm{rOFF}_{\mathrm{i}, \mathrm{t}}$ the relative offshoring indicator and $\mathrm{OIL}_{\mathrm{t}}$ the real oil price measured by the price of Brent oil deflated by core consumer prices.

\section{b- Econometric strategy}

Based on this export equation, we run a panel data analysis. We first run a F-test in order to test the presence of individual effects. The test result allows us to use a panel rather than a pooled estimation. Individual unobserved heterogeneity is controlled for by estimating a fixed effects version of the export equation. Using a Hausman specification test, we exclude a random effects model. However, time-fixed effects are rejected by a F-test. We, also test our model for the presence of heteroscedasticity in two different ways. First, we use the test proposed by Breusch and Pagan (1980) in order to test if the error term has a constant variance. Besides, we test for the presence of inter-individuals heteroscedasticity with a Wald test. Both tests allow us to accept the null hypothesis of homoscedasticity of our model. Therefore, the OLS estimator remains efficient. Finally, error autocorrelation is rejected by the Wooldridge test (2002).

Another potentially important methodological issue deserves careful study. Our variable of interest, the relative offshoring ratio, can suffer from an endogeneity bias, because it could be argued that offshoring not only affect exports, but that exports to some extent drive offshoring decisions (Erkel-Rousse and Garneiro, 2008). Therefore the Ordinary Least Squares (OLS) cannot be used and we have to refer to the two-least squares regression. We address this issue by instrumenting the offshoring ratio measures in equation (3). However, acceptable instruments are required for a proper instrumental variables method. The instruments must be correlated with the endogenous explanatory variables, conditional on the other covariates and cannot be correlated with the error term in the explanatory equation, that is, the instrument cannot suffer from the same problem as the original predicting variable.

A possible way to address endogeneity would be to use time lags of the relevant explanatory variables. To test whether the instruments are highly correlated with the endogenous variables a test of instrument relevance is performed. This test is based on the Kleibergen-Paap rk LM statistic (Kleibergen and Paap, 2006). Under the null hypothesis, the model is underidentified and the instruments are weak. If the test is rejected, the instruments are valid. The other important instruments characteristic is that they must be asymptotically 
uncorraleated with the regression disturbance. This test, of overall validity, is based on the Hansen J-statistic for the joint null hypothesis that the instruments are valid. The results of the tests allow us to use the second, third and fourth lags of our interest variable as instruments.

\section{Results}

We perform our export equation using a panel data analysis for France, Germany and Italy using quarterly data covering the period from the first quarter of 2001 to the fourth quarter of 2007. Table 3 summarizes estimation results using the pooled OLS, the OLS fixed-effect and the Instrumental Variables (IV).

Table 3: Estimation results, panel data

\begin{tabular}{|c|c|c|c|c|c|c|}
\hline \multirow[t]{2}{*}{ Variables } & \multicolumn{2}{|c|}{ Pooled OLS } & \multicolumn{2}{|c|}{ Fixed effect } & \multicolumn{2}{|c|}{ IV } \\
\hline & Coeff. & Std.err. & Coeff. & Std.err. & Coeff. & Std.err. \\
\hline $\mathrm{Ln}(\mathrm{WD})$ & -0.8359 & $0.1675 * * *$ & 0.3654 & $0.1850 *$ & 0.2525 & $0.1438 *$ \\
\hline $\operatorname{Ln}(\mathrm{ULC})$ & -2.2880 & $0.7450 * * *$ & -1.4244 & $0.5482 * *$ & 1.5848 & $0.6415 * *$ \\
\hline $\operatorname{Ln}(\mathrm{rRD})$ & 1.7124 & $0.0815 * * *$ & 1.0048 & $0.2020 * * *$ & 0.9998 & $0.1482 * * *$ \\
\hline Ln(PROD) & 2.3864 & $0.3550 * * *$ & 2.5465 & $0.1299 * * *$ & 2.4419 & $0.4289 * * *$ \\
\hline $\mathrm{Ln}(\mathrm{rCU})$ & 0.8261 & $0.2655 * * *$ & 0.3739 & $0.2020 *$ & 0.4745 & $0.2085 * *$ \\
\hline $\mathrm{Ln}(\mathrm{rOFF})$ & -2.0033 & $0.4989 * * *$ & -0.9950 & $0.3553 * * *$ & 10919 & $0.4371 * *$ \\
\hline $\operatorname{Ln}(\mathrm{PE})$ & -0.1028 & 0.0699 & -0.1981 & $0.0498 * * *$ & 0.1961 & $0.0559 * * *$ \\
\hline Constant & 23.6384 & $4.3935 * * *$ & 3.3827 & 3.8432 & - & - \\
\hline Method & & $\mathrm{LS}$ & & $\mathrm{LS}$ & & $\mathrm{LS}$ \\
\hline Hausman test & & & 98. & $3 * * *$ & & \\
\hline Wald test & & & & 00 & & \\
\hline Breusch-Pagan LR test & & & & 04 & & \\
\hline Wooldridge test & & & & 206 & & \\
\hline Kleibergen-Paap rk LM & & & & & 18. & $91 * * *$ \\
\hline Hansen J statistic & & & & & & 334 \\
\hline No. of observations & & 34 & & 4 & & 72 \\
\hline $\mathrm{R}^{2}$ & 0.9740 & adjusted) & 0.6214 & (within) & 0.550 & (within) \\
\hline
\end{tabular}

Across all three estimation methods, all variables are significant at the $10 \%$ level, except the constant in the pooled OLS estimation. We also see that the coefficients have the same sign in the fixed-effect regression and IV estimation. Only the pooled OLS estimation method gives wrong results about the world demand. In the IV estimation, we notice that we cannot reject the null hypothesis that the instruments are jointly valid, according to the Hansen J-test. Furthermore, the Kleibergen-Paap statistic shows us that our instruments are not underidentified in the estimation. Therefore, our instruments are valid. 
In line with the results of traditional export equations, we find that world demand and cost-competitiveness have respectively a significant and positive and significant and negative impact on countries' exports in the fixed-effect and the IV estimation. An increasing world demand reflecting a better geographical specialization is a factor of better export equation. On the contrary, the growth of unit labour costs is an obstacle to export growth. Furthermore, our indicator of non-price competitiveness (rRD) has a positive and significant impact on the dynamism of French, German and Italian exports of automotive with an elasticity of around 1 in the last two estimations. It means that vertical differentiation of production allows countries to find new markets and to sell more products. A few trademarks like Audi, BMW, Mercedes, Porsche (Germany) or Alfa Romeo, Ferrari, Lancia, Maserati (Italy) are specialized in highend cars, so that their exports depends much more on non-price competitiveness than pricecompetitiveness. It confirms the results of Ionnadis and Schreyer (1997) in a sector-based data analysis. We also find that relative relative capacity utilization ratio and productivity have significant and positive impact on French, German and Italian automotive exports. German automotive firms benefit heavily from their higher productivity in the automotive sector. As expected, the real oil price affects the automotive exports of the selected countries. This is in line with the previous analysis of Hugh et al. (2008).

Finally, we find that our offshoring indicator in the automotive sector has a significant and negative impact on countries exports with an elasticity near 1. An increase in international offshoring is therefore a key factor to better understand the export performance discrepancies among the three selected countries. Moreover, the French strategy of increasing international outsourcing could have explain the loss of French exports market-share.

The panel data results (fixed-effects OLS and IV) show that automotive exports are not only affected by competitiveness variables such as costs or quality, but also by the different offshoring strategy. Indeed, the firms which use the total relocation of production lower their exports via a "misapporpiation effect". The firms no longer export the final product and the home country is supplied by a foreign one. Nevertheless, this model does not allow an interpretation country by country and especially a comparison between France and Germany. In order to study this phenomenon for France and Germany we then have to run a time series model.

\section{France vs Germany}


We now focus our analysis on French and German automotive firms. We run our export equation for France and Germany using OLS and IV estimation. Our sample covers the period from the first quarter of 1997 to the third quarter of 2007. Our results are given in table 4.a for France and in table 4.b for Germany. 
Table 4: Estimation results for France and Germany

\begin{tabular}{|c|c|c|c|c|c|c|c|c|}
\hline \multicolumn{5}{|c|}{ 4.a FRANCE } & \multicolumn{4}{|c|}{ 4.b GERMANY } \\
\hline \multirow[t]{2}{*}{ Variables } & \multicolumn{2}{|c|}{ OLS } & \multicolumn{2}{|c|}{ IV } & \multicolumn{2}{|c|}{ OLS } & \multicolumn{2}{|c|}{ IV } \\
\hline & Coeff. & Std.err. & Coeff. & Std.err. & Coeff. & Std.err. & Coeff. & Std.err. \\
\hline$\overline{\mathrm{Ln}(\mathrm{WD})}$ & -0.8792 & "0.1675 & -1.5575 & (0.9538 & -0.1973 & "0.1632 & -0.1620 & 0.1235 \\
\hline Ln(ULC) & -0.5495 & $0.2854 * *$ & -0.4666 & $0.2292 * *$ & -1.7339 & $0.5021 * * *$ & -1.2221 & $0.4879 * * *$ \\
\hline $\operatorname{Ln}(\mathrm{rRD})$ & 0.5792 & $0.1386 * * *$ & 0.6156 & $0.1396^{* * *}$ & 1.0158 & $0.2380 * * *$ & 0.8250 & $0.2673 * * *$ \\
\hline $\mathrm{Ln}(\mathrm{PROD})$ & 0.9357 & $0.2766^{* * *}$ & 0.9893 & $0.2394 * * *$ & 1.4772 & $0.3189 * * *$ & 1.4143 & $0.3224 * * *$ \\
\hline $\mathrm{Ln}(\mathrm{rCU})$ & -0.3414 & 0.2073 & -0.3186 & $0.1732 *$ & 0.6961 & $0.3112 * *$ & 0.6232 & $0.2522 * *$ \\
\hline $\mathrm{Ln}(\mathrm{rOFF})$ & -0.9791 & $0.2675 * * *$ & -1.0326 & $0.1988 * * *$ & 0.4916 & 0.3789 & 0.4714 & 0.4067 \\
\hline $\operatorname{Ln}(\mathrm{PE})$ & 0.0457 & 0.0607 & 0.0316 & 0.0607 & 0.0248 & 0.0500 & 0.0827 & 0.0630 \\
\hline Constant & 17.2387 & 10.4707 & 25.3941 & 11.5620 & 10.8809 & $4.4965 * *$ & 8.6967 & $3.1863 * * *$ \\
\hline Method & \multicolumn{2}{|c|}{ OLS } & \multicolumn{2}{|c|}{$2 \mathrm{LS}$} & \multicolumn{2}{|c|}{ OLS } & \multicolumn{2}{|c|}{$2 \mathrm{LS}$} \\
\hline Breusch-Pagan test & \multicolumn{2}{|c|}{0.24} & \multicolumn{2}{|c|}{31.847} & \multicolumn{2}{|c|}{0.15} & \multicolumn{2}{|c|}{28.851} \\
\hline Kleibergen-Paap rk LM & & & \multicolumn{2}{|c|}{$15.048 * * *$} & & & \multicolumn{2}{|c|}{$22.629 * * *$} \\
\hline Hansen J statistic & \multirow{2}{*}{\multicolumn{2}{|c|}{44}} & \multicolumn{2}{|c|}{1.127} & \multirow{2}{*}{\multicolumn{2}{|c|}{44}} & \multicolumn{2}{|c|}{1.287} \\
\hline No. of observations & & & \multicolumn{2}{|c|}{42} & & & \multicolumn{2}{|c|}{41} \\
\hline $\mathrm{R}^{2}$ & \multicolumn{2}{|c|}{0.9119} & \multicolumn{2}{|c|}{0.9088} & \multicolumn{2}{|c|}{0.9129} & \multicolumn{2}{|c|}{0.6214} \\
\hline
\end{tabular}


Note that according to the tests on the instrumentals, variables we use the first and second lags for the offshoring ratio for France and the second and the third for Germany.

Our results show that the determinants of automotive exports are not the same for France and Germany. However, in both cases, the world demand, i.e. the geographical specialization had no impact on automotive exports.

Our findings also indicate that cost-competitiveness is a key factor to better understand export performances of France and Germany. Indeed, in both studies, cost-competitiveness has a significant and negative impact on French and German automotive exports. Therefore, the new "competitive disinflation" (Creel and Le Cacheux, 2006) lead by Germany since the end of the 1990s has allowed German automotive firms to be more competitive on the global market. On the contrary, the growing labour costs have penalized French automotive exports. In this way, between the second quarter of 2000 and the fourth quarter of 2007, the French unit labour costs in the automotive industry have increased around $16 \%$, whereas German ones have decreased by around $7 \%$. The better cost competitiveness of Germany is then an explanation of its "overperformance" on the world automotive market. This result is confirmed by the impact of productivity on export performances. Our model shows that productivity is significantly correlated with the evolution of exports in the automotive industry either for France and Germany. Germany has, therefore, benefited from its better productivity in the automotive industry. German productivity in the automotive sector has grown more than $50 \%$ between the first quarter of 2000 and the last quarter of 2007. During the same period, the French productivity in the automotive sector has remained relatively stable (it decreased by around $3 \%$ ). Our results concerning the non-price competitiveness ratio is also as we expected. Indeed, the relative $R \& D$ expenses variable has a significant and positive impact on both French and German automotive exports. It confirms the fact that German cars are sold in line with their trade mark or quality. It means that French and German automotive firms are brand sensitive.

The supply conditions measured by a ratio of relative capacity utilization (rCU) have a positive and significant impact on German exports performance in the automotive sector. It means that German automotive firms benefit from a high capacity utilization ratio which allow more exports. On the contrary, the relative capacity utilization ratio has no significant effect on the export performances of French automotive firms. 
Note that the real oil price is not a significant variable for explaining the growth of French and German automotive exports over the recent period.

As we expected, our relative international offshoring indicator has a significant and strong negative effect on French firms' exports in the automotive sector. Indeed the elasticity associated with the offshoring ratio is the strongest among explanatory variables. It means that offshoring is the main explanation of the evolution of French automotive exports. This finding confirms our hypothesis developed in section 2 that total relocation of production, in Slovenia for instance, has strongly decreased exports of French automotive firms. So, the relatively low export performance in the automotive sector arise more from an offshoring strategy than a price competitiveness problem. On the contrary, the offshoring ratio is not significant for explaining German automotive exports. This result confirms our hypothesis that German firms use intensively the new division of labour rather than the total relocation of production. In fact, German firms split the value-added chain in other countries with lower production costs. Contrary to French firms, they only offshore some stages of production. Then, German firms import semi-finished products, put them together and re-export them to the global market. It swells German exports in automotive products and increases the import content of export. Our results are in line with Erkel-Rousse and Garnero (2008).

Finally our model shows that France and Germany have two different models of growth for their automotive exports. If German automotive firms rely more on non-price competitiveness with a specialization in high-end vehicles, on their good cost competitiveness, productivity and capacity, French automotive firms rely more on an offshoring strategy which seriously decreases their exports from France.

\section{Conclusion}

In this paper the automotive export performances of France, Germany and Italy were estimated using the framework of "New Trade Theory" and "Vertical Specialization" which suggested augmenting the traditional model, in which exports are a function of export prices and foreign demand, with a non-price competitiveness variable proxied by the relative $R \& D$ expenditures and with an offshoring indicator calculated as the share of production carried abroad in the total production of automotive sector. We perform two analyses, (i) one using a panel for France, Germany and Italy and estimated with a fixed-effect model and the instrumental variables, and (ii) the other comparing the results for France and Germany. 
The econometric results from our panel are in line with the predictions of the theoretical model. It shows that export performances of selected countries depends on non-price competitiveness of products and on traditional variables (foreign demand and costcompetitiveness). It also shows that offshoring strategy entails a decrease in exports of the selected countries. But our panel data estimation hides several discrepancies among selected countries, especially for France and Germany.

When we look at a country analysis, we find that offshoring has different implications. Indeed, the increase in offshoring production has strongly diminished the automotive exports of French firms. Total relocation of production run by Renault in Slovenia had severely weighted the exports performances of France in the automotive sector. Contrary to France, German firms have split up stages of production in other countries so that more than half of their production is located in Germany. Then, German firms have taken advantage of the new division of labour. This strategy allows greater exports for Germans automotive firms.

Our work show that the relatively low export performance of France compared with Germany has three explanations: first, German automotive firms have benefited from lower labour costs conditions allowed by labour market reforms made by Germany over the recent period. Second, German automotive firms are highly specialized in high-end vehicles (Porsche, BMW, Audi, Mercedes), whereas France is more specialized in down and middlemarket vehicles (Renault and PSA). Third, German and French automotive firms have two different offshoring strategy: if German ones use more intensively the international product fragmentation, French ones prefer the total relocation of production in a foreign country. This strategy has seriously diminished French automotive exports on the world market. The data for from the OICA published in 2008 confirms this trend and in a few years, it is likely that most of the French cars will be produced in a foreign country, France being just specialized in high quality products. 
Appendix 1: World motor vehicle production by country (billion)

\begin{tabular}{|c|c|c|c|}
\hline & 1999 & 2008 & Evolution \\
\hline EU 15 & 16.929 & 15.170 & $-10 \%$ \\
\hline France & 3.180 & 2.569 & $-19 \%$ \\
\hline Germany & 5.688 & 6.041 & $6 \%$ \\
\hline Italy & 1.701 & 1.024 & $-40 \%$ \\
\hline Spain & 2.852 & 2.542 & $-11 \%$ \\
\hline United Kingdom & 1.974 & 1.650 & $-16 \%$ \\
\hline Eastern and Central Europe & 2.544 & 3.262 & $28 \%$ \\
\hline Czech Republic & 0.376 & 0.946 & $151 \%$ \\
\hline Hungary & 0.128 & 0.346 & $170 \%$ \\
\hline Poland & 0.575 & 0.951 & $65 \%$ \\
\hline Romania & 0.107 & 0.245 & $129 \%$ \\
\hline Slovak Republic & 0.127 & 0.576 & $354 \%$ \\
\hline Slovenia & 0.118 & 0.198 & $67 \%$ \\
\hline CIS & 1.234 & 2.180 & $77 \%$ \\
\hline Russia & 1.170 & 1.790 & $53 \%$ \\
\hline Turkey & 0.298 & 1.147 & $285 \%$ \\
\hline North America & 17.634 & 12.974 & $-26 \%$ \\
\hline Canada & 3.059 & 2.078 & $-32 \%$ \\
\hline Mexico & 1.550 & 2.191 & $41 \%$ \\
\hline USA & 13.025 & 8.705 & $-33 \%$ \\
\hline South America & 1.682 & 3.942 & $134 \%$ \\
\hline Brazil & 1.351 & 3.220 & $138 \%$ \\
\hline Asia-Oceania & 16.871 & 31.256 & $85 \%$ \\
\hline China & 1.830 & 9.345 & $411 \%$ \\
\hline India & 0.818 & 2.315 & $183 \%$ \\
\hline Japan & 9.895 & 11.564 & $17 \%$ \\
\hline South Korea & 2.843 & 3.807 & $34 \%$ \\
\hline Africa & 0.301 & 0.583 & $93 \%$ \\
\hline South Africa & 0.317 & 0.563 & $77 \%$ \\
\hline Total & 57.195 & 69.368 & $21 \%$ \\
\hline
\end{tabular}


Appendix 2: Production location of German, French and Italian automakers in 2007

\begin{tabular}{lccc}
\hline & French automakers* & German automakers** & Italian automakers*** \\
\hline \hline North America & - & 866900 & - \\
South America & 487940 & 882300 & 727399 \\
\hline Other UE-15 & 1253686 & 1696000 & 139179 \\
$\quad$ Spain & 1051812 & 1116961 & 65915 \\
\hline Central and Eastern Countries & 1150114 & 1260700 & 397163 \\
$\quad$ Czech Republic & 203135 & 621673 & - \\
Hungary & - & 56982 & 35451 \\
Poland & - & 354033 & 361712 \\
$\quad$ Romania & 222913 & - & - \\
$\quad$ Slovakia & 177628 & 203823 & - \\
$\quad$ Slovenia & 200187 & - & 78069 \\
\hline Asia & 679885 & 1044700 & 75233 \\
$\quad$ China & 212955 & 855427 & 189229 \\
\hline Africa & 39743 & 194700 & 1430 \\
Others & 1637 & & 1532469 \\
\hline Total foreign production & 3613005 & 5945300 & 1146982 \\
Domestic production & 2573248 & 6213000 & 2679451 \\
\hline Total production & 6186253 & 12158300 & $57 \%$ \\
\hline Share of foreign production & $58 \%$ & $49 \%$ & - \\
\hline Soure: Cra, VD, Ora & & \\
\hline
\end{tabular}

Source: $C C F A, V D A, O I C A$

Note: *: French automakers include PSA and Renault (including Renault Trucks)

**: German automakers include Audi, BMW, Opel, Porsche and Volkswagen

***: Italian automakers include Fiat-Iveco-Irisbus 
Appendix 3: Example of Vertical Specialization: Audi cars

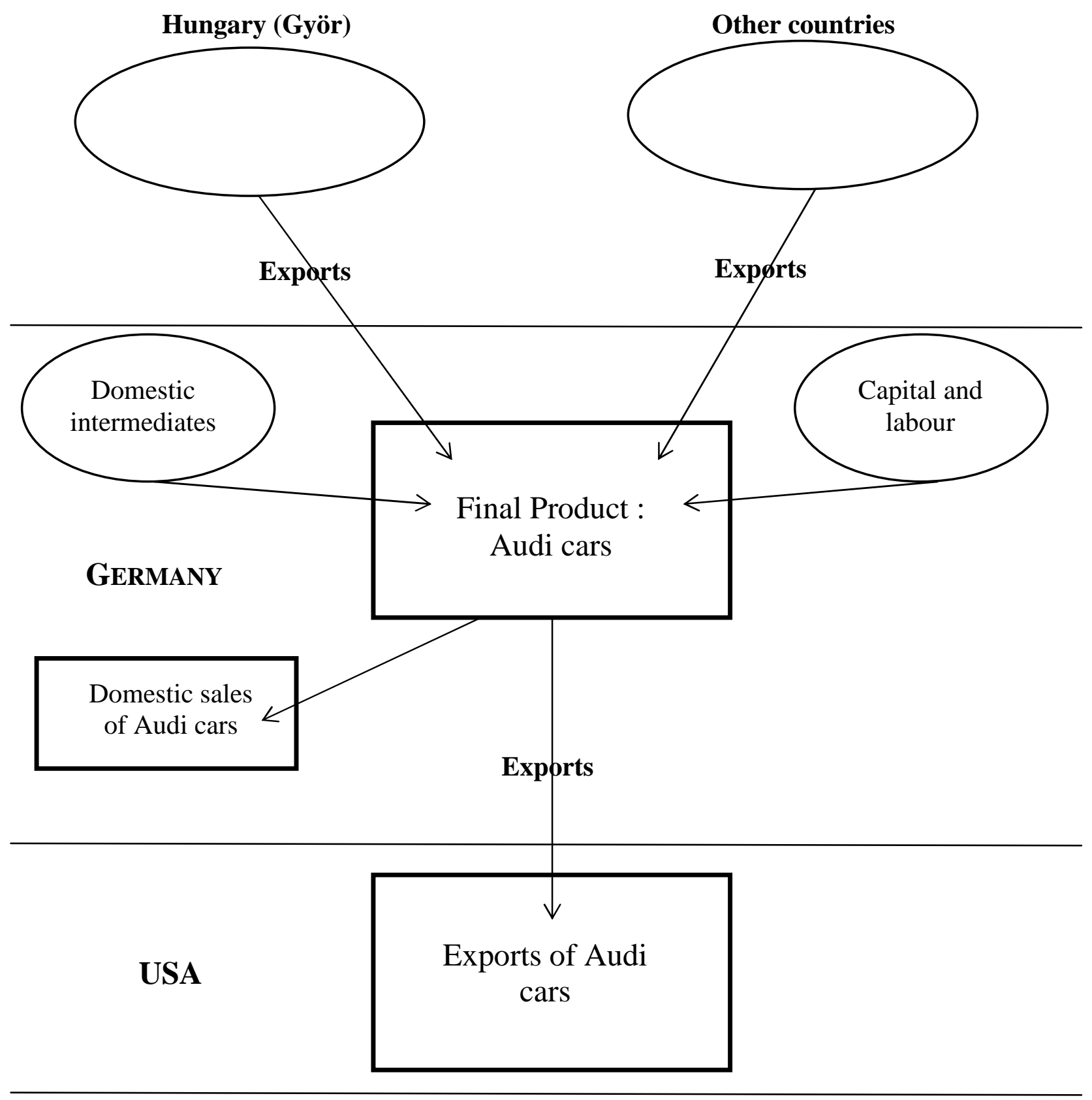


Appendix 4: Example of total offshoring: Renault Clio II

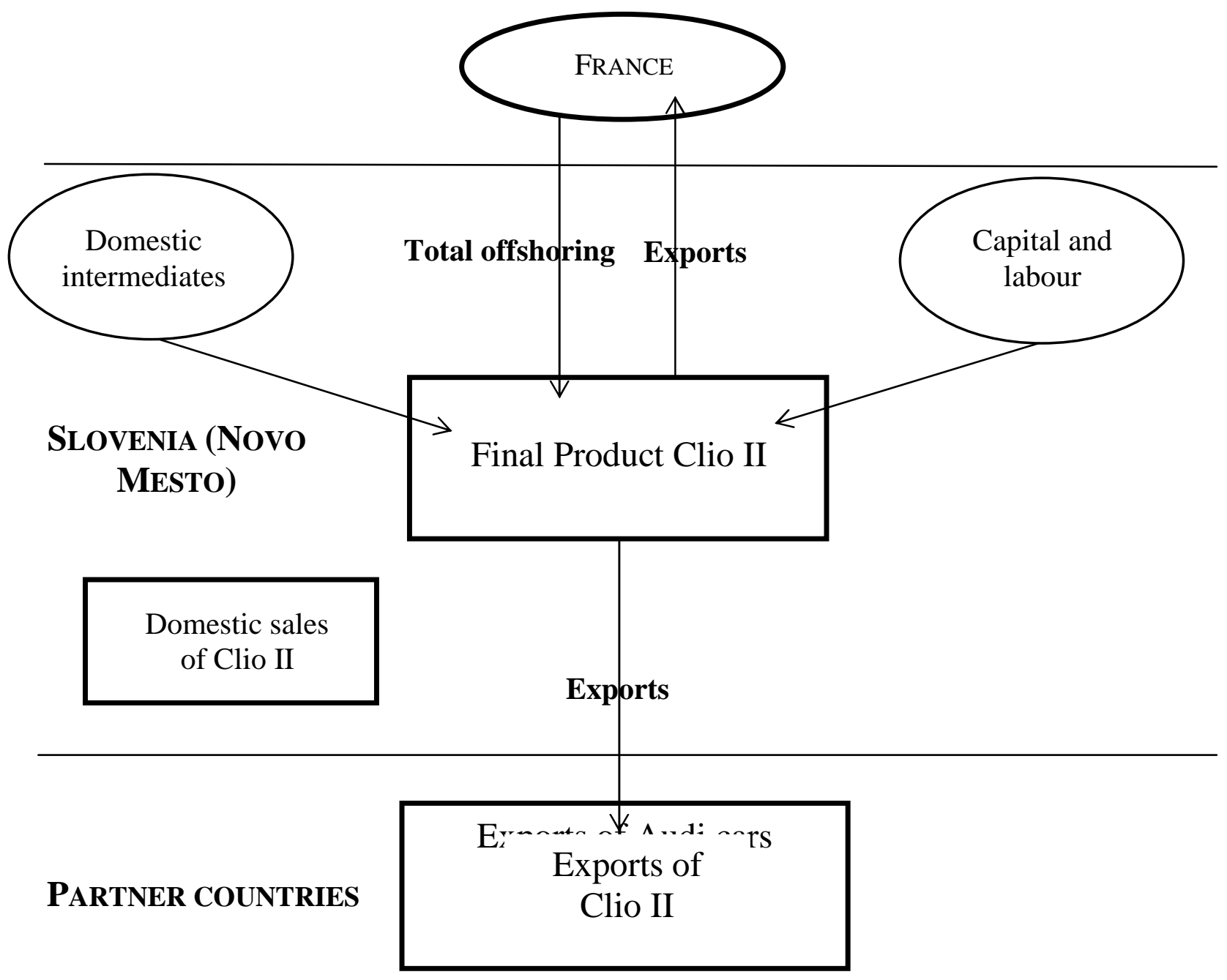


Appendix 5: Share of inland production in the total automotive production

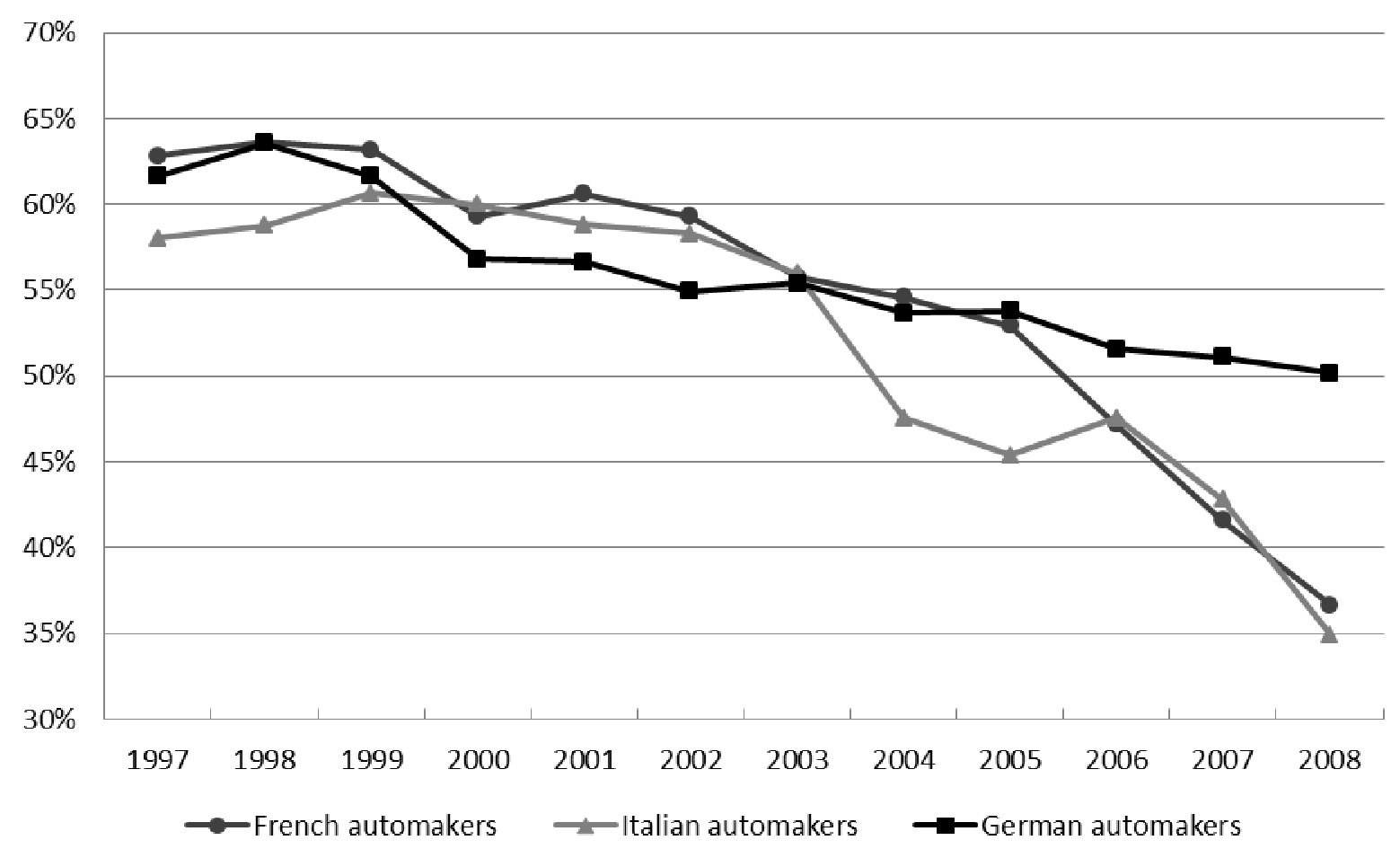

